\title{
Oral fibrosarcoma in jararaca (Bothrops pubescens): anatomopathological and immunohistochemical aspects ${ }^{1}$
}

\author{
Ezequiel D. Santos², José R. Silva Filho ${ }^{3}$, Tanise P. Machado², Stefano L. Dau', \\ Rubens Rodriguez ${ }^{5}$ and Adriana C. da Motta ${ }^{2 *}$
}

\begin{abstract}
Santos E.D., Silva Filho J.R., Machado T.P., Dau S.L., Rodriguez R. \& Motta A.C. 2015. Oral fibrosarcoma in jararaca (Bothrops pubescens): anatomopathological and immunohistochemical aspects. Pesquisa Veterinária Brasileira 35(7):664-670. Laboratório de Patologia Animal, Faculdade Agronomia e Medicina Veterinária, Universidade de Passo Fundo, Campus I, BR-285, Bairro São José, Passo Fundo, RS 99052-900, Brazil. E-mail: acmotta@upf.br

A 4-year-old female captive-bred snake of the genus Bothrops showed swelling on the left side of the oral cavity, suggesting the development of neoplasia. The mass was removed surgically and sent for pathological examination. Two months later a new increase in volume in the same site was observed, suggesting recurrence. The lesion was completely removed and sent for pathological analysis. Histologically, the two-samples consisted of a mass with highly-cell density composed of spindle-shaped anaplastic cells arranged in interwoven bundles, distributed throughout the tissue extension and, occasionally, polygonal cells arranged in irregular fascicles. The Masson trichrome staining showed modest amount of collagen supporting the neoplastic cells. PAS-positive content was not observed in the cytoplasm of neoplastic cells. Histological and histochemical findings indicated that it was a spindle cell neoplasm, but the classification was not possible. Immunohistochemistry was requested and performed using the streptavidin-biotin-peroxidase method. The markers used were anti-vimentin, anti-PCNA, anti-EMA, anti-melan A and anti-melanosome, anti-desmin, anti-actin, anti-CD68 and anti- S100protein. The neoplastic cells were immunoreactive for vimentin and PCNA and negative for the other antibodies. The morphology characterization, histochemical and immunohistochemical analysis of neoplastic cells allowed the definitive diagnosis of oral fibrosarcoma.
\end{abstract}

INDEX TERMS: Bothrops, snake, spindle cell neoplasm, fibrosarcoma, immunohistochemistry, vimentin, PCNA, histochemical.

RESUMO.- [Fibrossarcoma oral em jararaca (Bothrops pubescens): aspectos anatomopatológicos e imuno-histoquímicos.] Uma serpente de cativeiro, fêmea, quatro anos de idade, do gênero Bothrops apresentou aumento de vo-

\footnotetext{
${ }^{1}$ Received on February 27, 2015.

Accepted for publication on July 7, 2015.

${ }^{2}$ Laboratório de Patologia Animal, Faculdade de Agronomia e Medicina Veterinária (FAMV), Universidade de Passo Fundo (UPF), Campus I, BR 285, Bairro São José, Passo Fundo, RS 99052-900, Brazil. *Corresponding author: acmotta@upf.br

${ }^{3}$ Zoológico-UPF, Instituto de Ciências Biológicas, Universidade de Passo Fundo, Campus I, BR-285, Bairro São José, Passo Fundo, RS 99052-900.

${ }^{4}$ Veterinarian, Rua Vicente Prado Lima 465, Bairro Camobi, Santa Maria, RS 97105-390, Brazil.

${ }^{5}$ Instituto de Patologia de Passo Fundo (IPPF), Rua Teixeira Soares 885, Centro, Passo Fundo, RS 99010-081.
}

lume no lado esquerdo da cavidade oral, sugerindo tratar-se de neoplasma. A massa foi removida cirurgicamente e enviada para exame anatomopatológico. Dois meses depois foi observado novo aumento de volume no mesmo local, sugerindo recidiva. A lesão foi removida por completo e também enviada para análise. Histologicamente, as duas amostras consistiam de massa altamente celular, composta por células anaplásicas fusiformes organizadas em feixes entrelaçados e distribuídos por toda extensão tecidual e, ocasionalmente, células poligonais arranjadas em fascículos irregulares. A coloração de tricrômico de Masson apresentou quantidade modesta de colágeno sustentando as células neoplásicas. Não foi observado conteúdo PAS-positivo no citoplasma das células neoplásicas. Os achados histológicos e histoquímicos indicavam tratar-se de neoplasma de células fusiformes, porém não era possível sua classificação. A 
imuno-histoquímica foi requisitada e realizada pelo método streptavidina-biotina-peroxidase, utilizando os anticorpos anti-vimentina, anti-PCNA, Anti-EMA, anti-melan A, anti-HMB45, anti-desmina, anti-actina, anti-CD68 e anti-proteína S-100. As células neoplásicas foram imunorreativas para vimentina e PCNA e, negativas para os demais anticorpos. A caracterização morfológica, histoquímica e imuno-histoquímica das células neoplásicas permitiu o diagnóstico definitivo de fibrossarcoma oral.

TERMOS DE INDEXAÇÃO: Bothrops, serpente, neoplasma fusocelular, fibrossarcoma, imuno-histoquímica, vimentina, PCNA, histoquímica.

\section{INTRODUCTION}

The development of cancer is an important cause of morbidity and mortality for reptiles created and/or maintained in captivity (Garner et al. 2004). Retrospective studies conducted in zoos, demonstrate that the diagnosis of tumors in reptiles alternates between $2.3 \%$ and $9.8 \%$. Specifically in snakes, the same studies show tumor prevalence of $2.9 \%$, $12.4 \%$ and 15\% (Catão-Dias \& Nichols 1999, Garner et al. 2004, Sykes \& Trupkiewicz 2006). The expressive numbers demonstrate the reality of the last 20 years, where the improvement in the techniques of creating and maintaining snakes in captivity led to an increase the life expectancy of these animals and consequently manifestation of diseases yore underdiagnosed. Besides age, there are biological, physical and chemical factors associated with tumor development, such as viruses, radiation and cadmium, respectively (Schumacher et al. 1994, Wozniak et al. 2000, Orós et al. 2009).

The ophidians develop neoplasms in any part of the body, although digestive and tegumentary systems are most affected (Ramsay et al. 1996, Garner et al. 2004, Stern et al. 2010). Neoplasia in snakes present with the same histological types of neoplasms in mammals and birds. These can be of epithelial, mesenchymal or lymphoid origin, but mesenchymal is the most common (Kusewitt et al. 1997, Catão-Dias \& Nichols 1999, Stedman et al. 2010). Among the tumors of the oral cavity and the integument of snakes, fibrosarcoma is the most reported, followed by others that can occur in various body sites, such as melanoma, sarcoma, spindle cell carcinoma, squamous cell carcinoma, malignant lipoma, chromatophoroma and adenocarcinoma (Hernandez-Divers \& Garner 2003, Garner 2004, Cassali et al. 2004, Keck et al. 2011). However, there is still a lack of information and studies on the cause and the biological behavior of neoplasms in snakes, particularly concerning fibrosarcomas (Orós et al. 2009).

Until recently fibrosarcomas in snakes were considered locally invasive, with high recurrence and low metastatic potential (Garner 2004, Garner et al. 2004). However, recent studies have found high recurrent and metastatic behavior of this and other neoplasms in snakes and other reptiles (Ramis et al. 1998, Orós et al. 2004, Hes et al. 2007, Orós et al. 2009, Salinas et al. 2013, Sharpe et al. 2013). On clinical examination, the fibrosarcomas are presented as small or large nodular mass and soft to firm consistency, which impair biological functions of some snakes such as swallowing. When surgically removed and sectioned, the masses are grayish-white, firm and trabeculated. Histologically, the nodules are invasive, non-encapsulated and exhibit intense infiltrate of neoplastic spindle cells supported in fibrovascular stroma and arranged in interwoven bundles or trabeculae crisscrossing up. The cells may also exhibit variable pleomorphism, hyperchromatic nuclei and loss of nuclear-cytoplasmic ratio, in addition to atypical mitotic figures and multifocal areas of tumor necrosis (Garner et al. 2004, Gumber et al. 2010a, Gumber et al. 2010b, Salinas et al. 2013, Rose \& Higgin 2014). In many cases it is necessary to conduct special stains such as periodic acid-Schiff (PAS) and Masson trichrome. The use of histochemical helps in identifying the cell-type and intracellular components such as glycogen, as well as histological differentiation between tissues such as smooth muscle and collagen (Ramsay et al. 1996, Wozniak et al. 2000, Heckers et al. 2012, Sharpe et al. 2013).

Macroscopically the chronic inflammation and caseous granulomas may simulate the development of tumours in reptilians, especially with regard to deformity and tissue necrosis (Mauldin \& Done 2006). In this way it becomes essential to the collecting and forwarding of lesions for histopathological examination, because that provides a conclusive diagnosis and provides the correct oncology treatment. Moreover in inconclusive cases such as neoplasms with similar standard-cell to many tumors types, the using the techniques of histochemical and immunohistochemistry could help in defining the final diagnosis (Haines \& Clark 1991, Haines \& Chelack 1991, Mohanty \& Naik 1997, Barra 2006). In this context, this paper aims to report the occurrence of an oral fibrosarcoma in jararaca (Bothrops pubescens), describing and discussing the pathological, histochemical and immunohistochemical findings found in the case.

\section{MATERIALS AND METHODS}

Samples. Tissue fragments with tumor appearance were collected from the left side of the oral cavity of a jararaca (Bothrops pubescens) by anesthesia and surgery. The fragments were fixed in $10 \%$ buffered formalin and sent to the Laboratory of Animal Pathology University of Passo Fundo (LAP-UPF) for histopathological examination.

Pathology. The samples were processed by conventional histochemical methods, sectioned into three microns $(3 \mu \mathrm{m})$ and stained with hematoxylin and eosin (H\&E). Sections were subjected to special Masson trichrome (MT) staining, blushing in red the muscle cells and blue the collagen. We also performed out the periodic acid Schiff (PAS) staining for demonstration of PAS-positive cytoplasmic contents in the neoplastic cells. For immunohistochemistry (IHC) used the streptavidin-biotin-peroxidase method. Antigen retrieval was performed using citrate solution pH 6.0 and Tris-EDTA pH 9.5 in a pressure cooker at $100^{\circ} \mathrm{C}, 20$ minutes. The blocking of endogenous peroxidase was carried out incubating the slides in $10 \%$ solution of hydrogen peroxide for 10 minutes. To reduce the possibility of non-specific binding, slides were immersed for 20 minutes in $10 \%$ skim milk $\left(\right.$ Molico $^{\circledR}$ ) diluted in distilled water. The specificities of antigenic retrieval and the antibodies used, among other data, are shown in Table 1. The antibodies were diluted in phosphate buffer saline (PBS) and dispensed on the cuts. The slides were incubated in a moist chamber for 13 hours (overnight) at $4^{\circ} \mathrm{C}$ and then incubated with 
biotinylated secondary antibody linked to streptavidin-peroxidase (LSAB-HRP, K0690, DakoCytomation ${ }^{\circledR}$ ), 30 minutes each step at room temperature. For the revelation the chromogen 3,3'-diaminobenzidine (DAB, K3468, DakoCytomation ${ }^{\circledR}$ ) was used for two minutes. The slides were stained with hematoxylin for one minute, washed with water, dehydrated in alcohol, clarified with xylene, mounted with synthetic balsam and glass slides, and evaluated under a light microscope. To evaluate the protocols and reagents functionality, cuts for positive tissues were performed for each of the antibodies. These were inserted at technique during its realization (Table 1). The positive controls used were samples of skeletal muscle (vimentin and desmin), salivary gland (EMA), cutaneous melanoma fragment (melan A and HMB45), blood vessels (actin), lymph node (PCNA and CD68) and skin with peripheral nervous system (S100). For expression of the results were used methods of quantitative analysis (number of immunoreactive cells in 10 fields with enlargement of 400x) and qualitative (distribution, intensity and topography of neoplastic cells).
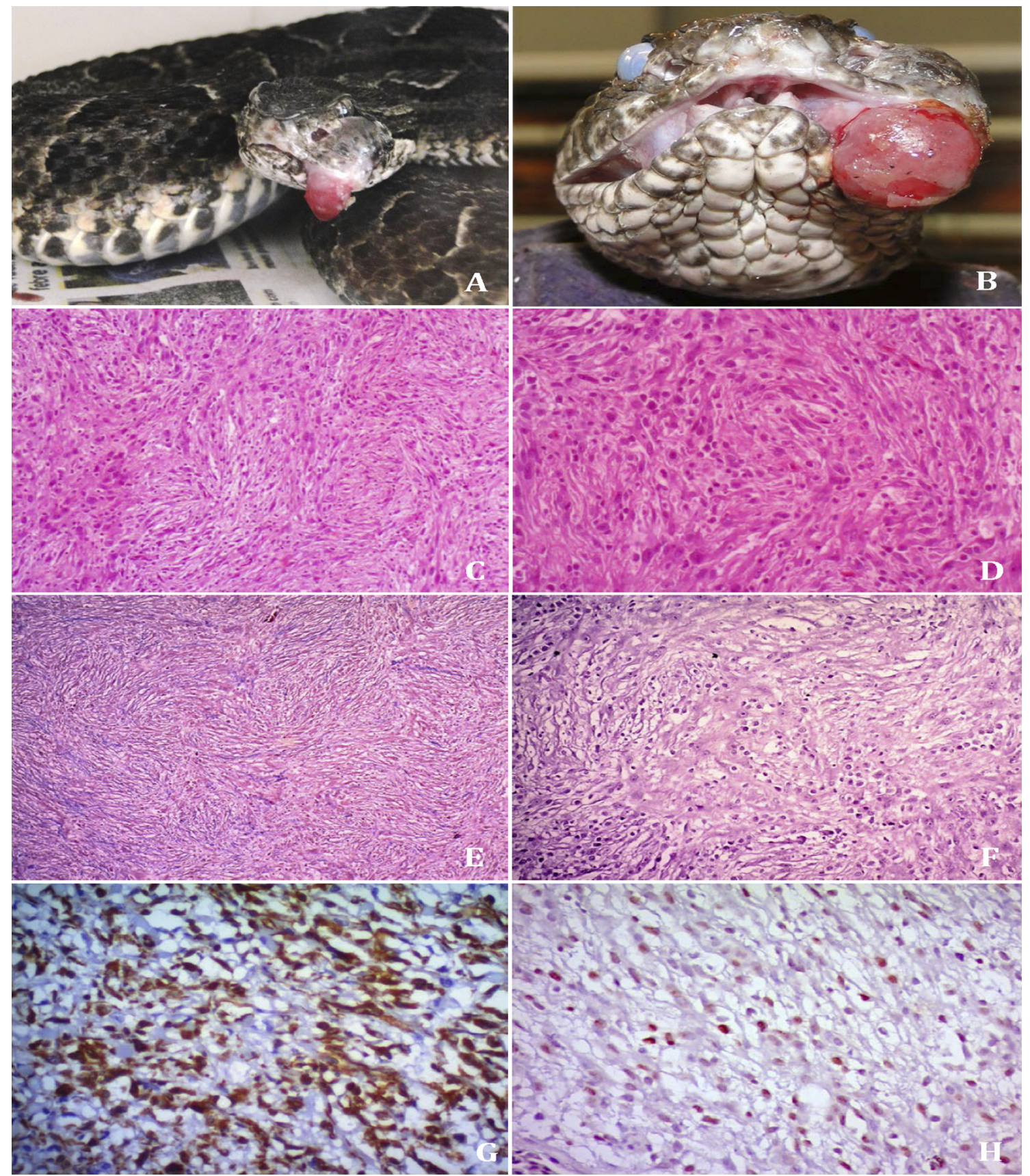

Fig.1. Oral fibrosarcoma in jararaca (Bothrops pubescens). (A) Tumor mass on the left side of the oral cavity. (B) Volume increase on the site of the primary tumor mass (relapse). (C) Disorganization of the parenchyma associated with a high number of fusiform neoplastic cells arranged in multidirectional bundles, sometimes criss-crossing. HE, 100x. (D) Disorganization of the parenchyma and the presence of anaplastic cells with intense cellular pleomorphism, hyperchromatic nuclei, and loss of the relationship between nuclei-cytoplasm. HE, 200x. (E) Modest amount of collagen supporting the neoplastic cells. MT, 50x. (F) Absence of neoplastic cells with PAS-positive content. PAS, 200x. (G) Positive cytoplasmic immunoreaction for vimentin. Immunohistochemical, Streptavidin-biotin-peroxidase method and counter-stained with hematoxylin, 200x. (H) Positive nuclear immunoreaction for PCNA. Immunohistochemical, Streptavidin-biotin-peroxidase method and counter-stained with hematoxylin, 200x. 


\section{RESULTS}

A snake, species Bothrops pubescens, 4-years-old, female, belonging to UPF Zoological (Zoo-UPF) began to show lethargy, anorexia and dysphasia for 30 days in addition to swelling on the left side of the oral cavity, suggesting neoplasm. (Figure 1A). The veterinarian responsible for Zoo-UPF opted for surgical removal of the mass in order to send it for anatomopathological analysis. After surgery, the snake remained under medical care and was treated with antibiotics for 15 days, avoiding contamination of the site of resection and subsequent sepsis. The tissue fragment was nodular, with ulcerated surface, firm consistency and whitish staining, measuring $0,8 \times 0,5 \times 0,5 \mathrm{~cm}$. The diagnosis was oral fibrosarcoma, by performing IHC.

Two months after the removal of the affected area, new swelling was observed on the site where the resection was performed, suggesting a recurrence (Figure 1B). Through the unfavorable diagnosis that already existed, the veterinarian opted for new surgical procedure, seeking the complete removal of the abnormal mass of tissue. The sample was sent for histopathological analysis and measured $2 \times 0,6 \times 0,8 \mathrm{~cm}$. Microscopically, both masses showed disorganization of parenchyma and high density of anaplastic spindle cells supported in the fibrovascular stroma. Neoplastic cells found themselves arranged in multidirectional bundles spread over whole extension of tissue (Figure 1C). Moreover there was marked pleomorphism, hyperchromatic nuclei, loss ratio nucleus cytoplasm and atypical mitotic figures (Figure 1D). The occasionally, had irregular polygonal cells arranged in fascicles as well as areas of tumor necrosis. Through the MT, modest amount of collagen was observed supporting the neoplastic cells (Figure 1E), tumor cells showed no evidence of PAS-positive cytoplasmic contents (Figure 1F).

Initially, the diagnosis of the first sample was malignant spindle cell neoplasm, not being possible to their classification by means of histochemical techniques. Thus was required realization of immunohistochemistry to verify histogenesis and immunostaining of cell-specific proteins and thus allow accurate diagnosis in this unusual taxon. The same way we proceeded to with the second sample, in order to prove that it was a recurrence of primary neoplasm. Neoplastic cells in both samples were immunoreactive to vi- mentin and PCNA (20 immunoreactive cells in high power field, 10 fields, 400x), (Figure 1G, H). And were negative for markers anti-EMA, anti melan-A, anti-HMB45, anti-desmin, anti-actin, anti-CD68 and anti-protein S-100 (Table 1). Based on morphological observations, histochemical and immunohistochemical of neoplastic cells was possible to conclude that the neoplasm was an oral fibrosarcoma.

\section{DISCUSSION}

The paper describes the clinical presentation, macroscopic findings, histological, histochemical and IHC in a snake Bothrops of genus diagnosed with oral fibrosarcoma. Regarding age, the present case contradicted what the literature proposes for neoplasm in snakes, considering that the known prevalence is located between nine and twenty years old (Catão-Dias \& Nichols 1999, Garner et al. 2004, Sykes \& Trupkiewicz 2006). The occurrences of fibrosarcoma in young snakes have been observed in other studies (Hes et al. 2007). Although age is considered an important risk factor in the development of neoplasms and other diseases in reptiles, well as in mammals, there is the influence of additional factors. Some studies have demonstrated the action of biological, physical and chemical agents associated with tumor development, such as viruses, radiation and cadmium, respectively (Schumacher et al. 1994, Wozniak et al. 2000, Orós et al. 2009).

Regarding clinical presentation, the serpent presented signs mostly frequent observed in reptiles neoplasm, such as lethargy, dysphasia, anorexia and emaciation (Ramis et al. 1998, Garner et al. 2004, Sykes \& Trupkiewicz 2006). In general, the clinical manifestations are associated with the affected systems. In the case of tumors in the mouth, as in the case reported, the swelling can compress areas sensitive to pain and necessary to the senses of predator. It can also compress viscera and/or obliterate the gut, preventing swallowing. Being an intensely irrigated area also constitutes an excellent venue for dissemination of neoplasic cells to other parts and organs (Hes et al. 2007, Gumber et al. 2010b).

The presentation of the tumor in the mouth of the serpent and the macroscopic characteristics of the samples sent for pathological examination are consistent with those described for sarcomas in reptiles, birds and mammals

Table 1. Primary antibodies with your codes and clones, dilutions, antigen retrieval buffer, positive controls reactions and reactions in the study

\begin{tabular}{|c|c|c|c|c|c|c|}
\hline Antibody & Dilution & $\begin{array}{c}\text { Antigen retrieval } \\
\text { buffer }\end{array}$ & Clone & Code & $\begin{array}{l}\text { Positive } \\
\text { control }\end{array}$ & $\begin{array}{c}\text { Reaction in } \\
\text { study** }\end{array}$ \\
\hline \multicolumn{7}{|l|}{ Monoclonal } \\
\hline Mouse anti-vimentin* & $1: 100$ & Citrate pH 6.0 / 20’ & V9 & M 0725 & + & + \\
\hline Mouse anti-PCNA* & $1: 400$ & Citrate pH 6.0 / 20' & PC10 & M 0879 & + & + \\
\hline Mouse Anti-Human EMA* & $1: 100$ & Citrate pH 6.0 / 20' & E29 & M 0613 & + & - \\
\hline Mouse anti-human Melan $A^{*}$ & $1: 100$ & Citrate pH 6.0 / 20' & A103 & M 7196 & + & - \\
\hline Mouse anti-human Melanosome * & * $1: 200$ & Citrate pH 6.0 / 20' & HMB45 & M 0634 & + & - \\
\hline Mouse anti-human Desmin* & $1: 100$ & Citrate $\mathrm{pH} 6.0$ / 20' & D33 & M 0760 & + & - \\
\hline Mouse anti-human Actin* & $1: 100$ & Citrate pH 6.0 / 20' & $1 \mathrm{~A} 4$ & M 0851 & + & - \\
\hline Mouse anti-human CD68* & $1: 100$ & Tris-EDTA pH 9,5 / 20' & KP1 & M 0814 & + & - \\
\hline \multicolumn{7}{|l|}{ Polyclonal } \\
\hline Rabbit anti-S100* & $1: 100$ & Citrate pH 6.0 / 20’ & - & Z 0311 & + & - \\
\hline
\end{tabular}


(Kusewitt et al. 1997, Goldschmidt and Hendrick 2002, Garner et al. 2004). According to the work of Hes et al. (2007), Salinas et al. (2013) and Rose \& Higgins (2014), fibrosarcomas may present as small or large nodular masses, with soft to hardened consistency, the cuts exhibit whitish or grayish, sometimes trabeculated areas due to fibrovascular stroma of the tumor. The ulceration is not part of the characteristics of fibrosarcoma. Its occurrence, in our case, can be explained by the location of the nodule, given that the lump protruded out of the oral cavity, suffering all kinds of friction. Recent studies have found high recurrent and metastatic potential of this neoplasm in snakes and other reptiles (Ramis et al. 1998, Orós et al. 2004, Hes et al. 2007, Orós et al. 2009, Salinas et al. 2013, Sharpe et al. 2013). In our case there was recurrence of fibrosarcoma in about 60 days after surgical removal of the primary nodule. However, after complete removal of relapse, the snake had follow-up for several months and showed no evidence of metastasis.

Histological evaluation of the samples sent to the LAP-UPF demonstrated classic alterations for fibrosarcomas and partly classic to several other neoplasms. Histologically, the samples were predominantly consisting of high density anaplastic spindle-shaped cells distributed along the full extent of the samples, and disorganization intense of parenchyma. The Works of Elkan (1974), Forcelledo (2003), Garner et al. (2004) and Manoel et al. (2008) agree that the spindle cell pattern is common in many sarcomas, and this analogy has been the cause of many mistakes when classifying them. Among spindle cell sarcomas that may present fusocellular standard, the authors cite: amelanotic melanomas, the neurofibrosarcomas, schwannoma, leiomyosarcoma, rhabdomyosarcoma, mixosarcomas and peripheral nerve sheath tumors. Although the samples had areas with spindle cells arranged in bundles multidirectional and often crisscrossing up, classic arrangement of fibrosarcoma, there were no subsidies, sufficient to classify the neoplasm. The special staining with MT showed modest amount of collagen in the stroma, which can vary due to the degree of differentiation of fibrosarcomas, as well as in other spindle cell sarcomas (Speltz et al. 2007). In PAS, the findings did not show agreement in relation to fibrosarcomas. According to literature, the tumor cells of fibrosarcomas may exhibit metachromasia confined to the membranes, but do not show PAS-positive cytoplasmic contents. Already the peripheral nerve sheath tumor (PNST), considered differential diagnosis of this case presents accumulation of PAS-positive content in the cytoplasm. The PNST can also present heterologous component in the tumor mass as bone, cartilage, glandular or squamous epithelium and skeletal muscle (Pinheiro \& Xavier 2003, Speltz et al. 2007, Sharpe et al. 2013). Given the atypical findings, the histochemical was not sufficient for the definitive diagnosis; however, allowed to disregard other neoplasms and direct which antibodies they should be used in the IHC for differentiation and classification of sarcomas.

For the case in question, the immunohistochemistry demonstrated good results in the detection of tumor antigens in Snakes. The cytoplasmic immunoreactivity of neoplastic cells for vimentin, that is an intermediate filament, confirmed their mesenchymal lineage. The nuclear immunostaining for PCNA showed intense replication and/or repair of DNA molecules of neoplastic cells indicating that these cells had higher cell division, which characterizes its malignant phenotype (Hall et al. 1990). It is worth mentioning that negativity for anti-EMA, anti-melan A, anti-HMB45, markers anti-desmin, anti-actin, anti-CD68 and anti-protein S-100, also contributed to the accurate diagnosis. The negative results allowed rule out other possibilities neoplastic, such as tumors of perineural cells (EMA), amelanotic melanoma (melanoma A-100 and S HMB45), rhabdomyosarcoma (desmin), leiomyosarcoma (actin), histiocytoma (CD68) and tumors of the nerves peripheral (S-100), revealing it was case of an oral fibrosarcoma.

The study of Hes et al. (2007) evaluated molecularly two samples diagnosed with fibrosarcoma, in order to perform a comparative analysis of the classification of fibrosarcomas in snakes and humans. At work, the authors used a broad panel of antibodies containing the markers anti: vimentin, CD68, cytokeratin (AE1/AE3), desmin, EMA, K903, CAM 5.2, actin E, actin S, MyoD1, S-100, HMB45 and Ki67. Immunostaining demonstrated, for both snakes, only for vimentin and the reaction was considered false-negative for Ki-67. The Ki 67 is a nuclear marker for proliferating cells, which should have produced positive immunoreactivity. Their negativity can be attributed to sample in formalin superfixation, failures in implementing the protocol or due to nonspecific antibody (anti-human) against an antigen (reptilian) (Haines \& Clark 1991, Haines \& Chelack 1991, Mohanty \& Naik 1997, Barra 2006). However, it is noteworthy that in our case, an antibody for the same purpose (PCNA) was used with great results, showing about 20 immunoreactive cells in high power field (10 fields, 400x).

The work of Marcello Junior et al. (2002) also describes a standard spindle cell neoplasm in a snake (Bothrops leucurus). The IHC was performed using antibodies against vimentin, smooth muscle actin, desmin, myoglobin, glial fibrillary acidic protein (GFAP) and S-100 protein. The results were negative for actin, desmin and myoglobin and inconclusive for vimentin, GFAP and S-100. Given the molecular results, the diagnosis was spindle cell sarcoma of undetermined histogenesis. The immunohistochemical evaluation of a snake sarcoma (Sanzinia madagascariensis) employing the antibodies, anti-vimentin, anti-major histocompatibility complex class II (MHC II) and anti-lysozyme showed no success in working of Sharpe et al. (2013). Similarly, there was no success in the work of Gumber et al. (2010 ${ }^{\mathrm{b}}$ ) using the antibodies anti-vimentin, anti-actin, anti-desmin, anti-protein S-100 and anti-enolase neuro-specific. Already at work Ramis et al. (1998), the molecular examination of the tumor presented by a snake (Agkistrodon pisciivorus) showed intense immunoreactivity to S-100 protein, which is present in cells derived from the neural crest, Schwann cells and melanocytes. Also there was moderate labeling for vimentin and negative for actin and F-VIII. These results were used to characterize and classify the neoplasm as malignant tumor of the peripheral nerve sheath. In the work 
of Petterino et al. (2006), conducting molecular studies of a neoplasm of spindle cell pattern of the corn snake (Elaphe guttata guttata), suggesting sarcoma, it was essential to define the epithelial origin of the neoplasm, through the expression of the marker AE1/AE3, confirming the diagnosis of undifferentiated carcinoma of the ovary. The examination showed positive immunostaining for smooth muscle actin, skeletal muscle actin and cytokeratin (AE1/AE3) and there was no labeling for vimentin and desmin.

Given discrepancy in the results of IHC for tumors in snakes, it is essential that the main factors responsible for these differences are identified, discussed and taken into consideration by research centers and diagnosis. Factors as the difference between the most used protocols and reagents must be considered in order minimizing them. The hyper-fixation samples, namely exacerbated period that they remain in formalin before being processed, must also be avoided. From a molecular standpoint, the diagnostic centers they should institute a rule not exceed 24 hours of sample exposure to formaldehyde. Thus, the sample would have a good chance of responding well to an immunohistochemical examination, decreasing the chances of nonspecific marking (false positive) or absent (false-negative) in a potentially positive sample (Barra 2006). Although controversial, some authors attribute the inefficiency of test, due to use of antibodies generated against human cell antigens in groups with low gene homology, such as snakes. That paradigm is being broken, in the case reported as in other studies, the use of anti-human antibodies worked well in diagnostic screening for tumors of reptiles. Thus we highlight the importance of this report, one of the few cases reported in snakes in the Brazil, where the immunohistochemical examination was successfully applied for definitive diagnosis.

\section{CONCLUSION}

Recent studies have demonstrated how the reptiles are susceptible to aggressive tumors which compromise the welfare and lives of these animals. The occurrence of neoplasms in reptiles, especially in snakes, is often underdiagnosed, not revealing the true incidence and prevalence. Among the causes for this to happen are: the lack of knowledge about the occurrence of tumors in reptiles, lack of collection and shipment of lesions for diagnosis, besides the unavailability of complementary techniques for accurate diagnosis in laboratories pathology, such as immunohistochemistry. In the present case for example, the IHC showed good results in the detection of tumor antigens, allowing for the diagnosis of fibrosarcoma in the oral cavity of a Bothrops pubescens."

\section{REFERENCES}

Barra M.B. 2006. 0 uso da imunoistoquímica no diagnóstico: indicações e limitações. Revta AMRIGS 50(2):173-184.

Cassali G.D., Amaral V.F., Silva A.E., Moacri I. \& Maciel R. 2004. Cytological and histopathological aspects of lipomas in Bothrops moojeni. Arq. Bras. Med. Vet. Zootec. 56(6):799-801.

Catão-Dias J.L. \& Nichols D.K. 1999. Neoplasia in snakes at the National Zoological Park, Washington, DC (1978-1997). J. Comp. Pathol. 120:89-95.
Elkan E. 1974. Malignant melanoma in a snake. J. Comp. Pathol. 84(1):51-57.

Forcelledo M.F.F. 2003. Curso corto sobre tumores de partes blandas. XXI Congreso de la sociedad española de anatomía patológica (SEAP), Madri, Espanha. Available in: <http://www.conganat.org/seap/congresos /2003/cursopartesblandas/fresno.htm> Access on Sept. 10, 2014.

Garner M.M. 2004. Trends in reptilian neoplasia: a diagnostician's perspective. Work presented at $55^{\text {th }}$ Annual meeting of the American College of Veterinary Pathologists (ACVP) and $39^{\text {th }}$ Annual Meeting of the American Society of Clinical Pathology (ASVCP). International Veterinary Information Service (IVIS), Ithaca, New York. 4p.

Garner M.M., Hernandez-Divers S.M. \& Raymond J.T. 2004. Reptile neoplasia: a retrospective study of cases submissions to a specialty diagnostic service. Vet. Clin. North Am., Exot. Anim. Pract. 7(3):653-671.

Goldschmidt M.H. \& Hendrick M.J. 2002. Tumors of the skin and soft tissues, p.45-118. In: Meuten D.J. (Ed.), Tumors in Domestic Animals. 4th ed. Iowa State Press, Ames. 788p.

Gumber S., Orandle M., Wakamatsu N. \& Cho D.Y. 2010a. Spindle cell tumors in snakes. Vet. Pathol. 47(6_Suppl.):18.

Gumber S., Nevarez J.G. \& Cho D.Y. 2010b. Endocardial fibrosarcoma in a reticulated python (Python reticularis). J. Vet. Diagn. Invest. 22:10131016.

Haines D.M. \& Clark E.G. 1991. Enzyme immunohistochemical staining of formalin-fixed tissues for diagnosis in veterinary pathology. Can. Vet. J. 32(5):295-302.

Haines D.M. \& Chelack B.J. 1991. Technical considerations for developing enzyme immunohistochemical staining procedures on formalin-fixed paraffin-embedded tissues for diagnostic pathology. J. Vet. Diagn. Invest. 3(1):101-112.

Hall P.A., Levison D.A., Woods A.L., Yu C.C., Kellock D.B., Watkins J.A., Barnes D.M., Gillett C.E., Camplejohn R., Dover R., Wassen N.H. \& Lane D.P. 1990. Proliferating cell nuclear antigen (PCNA) immunolocalization in paraffin sections: an index of cell proliferation with evidence of deregulated expression in some neoplasms. J. Pathol. 162(4):285-294.

Heckers K.O., Aupperle H., Schmidt V. \& Pees M. 2012. Melanophoromas and Iridophoromas in Reptiles. J. Comp. Pathol. 146(2-3):258-268.

Hernandez-Divers S.M. \& Garner M.M. 2003. Neoplasia of reptiles with an emphasis on lizards. Vet. Clin. North Am., Exot. Anim. Pract. 6(1):251273.

Hes O., Hnízdo J., Honsa V., Grégrová L. \& Benda J. 2007. Fibrosarkomy u hadů: klinická, morfologická, imunohistochemická, ultrastrukturální a srovnávací analýza dvou případů. Veterinární lékař. 5:49-55.

Keck M., Zimmerman D.M., Ramsay C.E., Douglass M. \& Reavill D.R. 2011. Renal adenocarcinoma in cape coral snakes (Aspidelaps lubricus lubricus). J. Herpt. Med. Surg. 21(1):5-9.

Kusewitt D.F., Reece R.L. \& Miska K.B. 1997. S-100 immunoreactivity in melanomas of two marsupials, a bird, and a reptile. Vet. Pathol. 34(6): 615-618.

Manoel W.J., Sarmento B.J.Q., Silveira Junior L.P., Abreu D.C.B., Abreu Neto I.P. \& Ferreira E.C. 2008. Sarcomas de alto grau: estudo retrospectivo de 131 casos. Rev. Col. Bras. Cirur. 35(2):83-87.

Marcello Junior H.B., Maciel R., Ribeiro C.A., Caliari M.V. \& Cassali G.D. 2002. Spindle cell sarcoma in Bothrops leucurus. Arq. Bras. Med. Vet. Zootec. 54:325-327.

Mauldin G.N. \& Done L.B. 2006. Oncology, p.299-322. In: Mader D.R. (Ed.), Reptile Medicine and Surgery. 2nd ed. Saunders Elsevier, Saint Louis. 1264p.

Mohanty K.C. \& Naik D.R. 1997. Immunohistochemistry and tinctorial affinity of adenohypophysial cells of the rat snake Ptyas mucosus (Colubridae). Gen. Comp. Endocrinol. 105(3):302-313.

Orós J., Tucker S., Fernández L. \& Jacobson E.R. 2004. Metastatic squamous cell carcinoma in two loggerhead sea turtles Caretta caretta. Dis. Aquat. Organ. 58:245-250.

Orós J., Monagas P., Andrada M., Calabuig P. \& Pether J. 2009. Metastatic fibrosarcoma in a captive Saharan horned viper (Cerastes cerastes) with high hepatic levels of cadmium. Vet. Rec. 164(22):690-692. 
Petterino C., Bedin M., Podestà G. \& Ratto A. 2006. Undifferentiated tumor in the ovary of a corn snake (Elaphe guttata guttata). Vet. Clin. Pathol. 35(1):95-100.

Pinheiro M.L. \& Xavier J.G. 2003. Estudo histoquímico da matriz extracelular de tumores de partes moles. Braz. J. Vet. Res. Anim. Sci. 40 (Suppl.): 216-217.

Ramis A., Pumarola M., Fernandez-Mora'n J., Añor S., Majó N. \& Zidan A. 1998. Malignant peripheral nerve sheath tumor in a water moccasin (Agkistrodon piscivorus). J. Vet. Diagn. Invest. 10(2):205-208.

Ramsay E.C., Munson L., Lowenstine L. \& Fowler M.E. 1996. A retrospective study of neoplasia in a collection of snakes. J. Zoo Wildl. Med. 27(1):28-34.

Rose K. \& Higgin D. 2014. Fibrosarcoma in a yellow anaconda (Eunectes notneus) [case 1598.1]. Australian Registry of Wildlife Health. Taronga Conservation Society Australia. Mosman, Australia. Available in: <http://203.41.141.168/sites/default/files/files-uploads/Case $\% 20$ 1598.1\%20Fibrosarcoma\%20in\%20a\%20Yellow\%20Anaconda.pdf> Access on Sept. 10, 2014.

Salinas E.M., Arriaga B.O.A., Lezama J.R., Bernal A.M. \& Garrido S.J.L. 2013. Oral fibrosarcoma in a black iguana (Ctenosaura pectinata). J. Zoo Wildl. Med. 44(2):513-516.
Schumacher J., Jacobson E.R., Homer B.L. \& Gaskin J.M. 1994. Inclusion body disease in boid snakes. J. Zoo Wildl. Med. 25(4):511-524.

Sharpe S., Lamm C.G. \& Killick R. 2013. Intracoelomic anaplastic sarcoma in an intersex Madagascar tree boa (Sanzinia madagascariensis). J. Vet. Diagn. Invest. 25(1):153-157.

Speltz M.C., Manivel J.C., Tobias A.H. \& Hayden D.W. 2007. Primary cardiac fibrosarcoma with pulmonary metastasis in a Labrador retriever. Vet. Pathol. 44(3):403-407.

Stedman N.L., Ball R.L. \& Burton M.S. 2010. Lymphosarcoma with respiratory and oral cavity epitheliotropism in a Boa constrictor. Vet. Pathol. 47(6_Suppl.):56.

Stern A.W., Velguth K.E. \& D’Agostino J. 2010. Metastatic ductal adenocarcinoma in a western hognose snake (Heterodon nasicus). J. Zoo Wildl. Med. 41(2):320-324.

Sykes J.M. \& Trupkiewicz J.G. 2006. Reptile neoplasia at the Philadelphia Zoological Garden, 1901-2002. J. Zoo Wildl. Med. 37(1):11-19.

Wozniak E., McBride J., DeNardo D., Tarara R., Wong V. \& Osburn B. 2000. Isolation and characterization of an antigenically distinct 68 - $\mathrm{kd}$ protein from nonviral intracytoplasmic inclusions in Boa constrictors chronically infected with the inclusion body disease virus (IBDV: Retroviridae). Vet. Pathol. 37(5):449-459. 